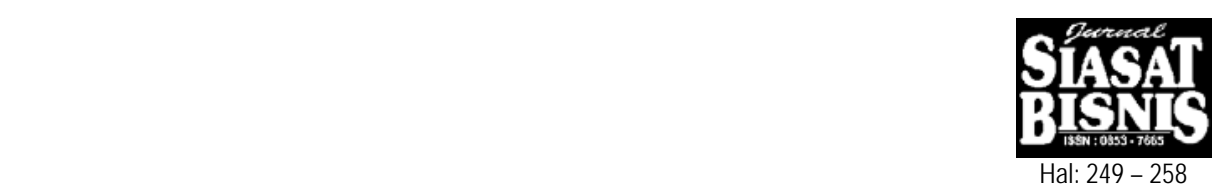

\title{
KEPUTUSAN MIGRASI SIRKULER PEKERJA SEKTOR FORMAL DI KOTA MEDAN
}

\author{
Muhammad Rizal \\ Universitas Negeri Medan
}

\begin{abstract}
This research conducted to analyze about factors influencing society decision of who live in beyond the city to migration of circular in Medan what variable of work Type, level of education, facilities of the city, the disadvantageous of villages, the ownership of land; influence the migration circular in the Medan. Population in this research is society working in formal sector in Medan, Technique of Intake of sample used is convience sampling that is by collecting data sample from a available information or source regardless of characteristic sample (Sekaran, 1992). From 200 quistioner which is spread there are 128 responder data which can be processed by using SPSS.10.0 regration

Result of this research find there are influence between: Work type, level of education, city facilities, villages disadvantages, ownership of land; influence the migration circular in Medan with degree of probability 0,005 with the level significance 0.05 , this research explain $12.3 \%$ migration of circular Medan affected by researched variable and rest is affected by other variable. This research also find that only variable of work type which by partial influence the society to conduct the migration to Medan with the probability 0.002 with the level significance $0.005 \%$.
\end{abstract}

Keywords: Migration Circular, The Disadvantageous Of Villages, City Attraction

\section{PENDAHULUAN}

Penduduk merupakan salah satu modal dasar pembangunan. Tetapi jumlah penduduk yang bertambahnya semakin pesat akan menimbulkan berbagai permasalahan bagi pembangunan. Demikian pula Indonesia sebagai negara berkembang yang memiliki ciri labour surplus economy dan memiliki jumlah penduduk yang keempat terbesar dunia.

Permasalahan yang ditimbulkan akibat pertambahan penduduk yang pesat di antaranya masalah ketenagakerjaan, kesempatan kerja yang dikaitkan dengan peluang ekonomi yang diperoleh. Misalnya penduduk dipandang sebagai konsumen, semakin banyak penduduk, semakin besar permintaan terhadap barang jasa. Artinya negara yang berpenduduk jumlah besar merupakan pasar yang sangat potensial bagi peningkatan perekonomian.

Namun ketika krisis mulai terjadi pada akhir tahun 1997 yang ditandai dengan meningkatnya nilai mata uang dolar, hal ini sangat berpengaruh terhadap harga barang di pasar domestik terutama barang impor kebutuhan pokok. Akibat dari terdepresiasinya nilai rupiah tersebut, harga barang terus meningkat. Gejolak lain yang terjadi di bidang ekonomi, di antaranya melemahnya kegiatan dunia usaha, terutama pekerja di sektor formal, yang berdampak meningkatnya pengangguran, menurunnya upah riil, menurunnya pendapatan perkapita, menurunnya daya beli masyarakat, 
pertumbuhan ekonomi negatif serta tingginya angka inflasi. Menurut data BPS Propinsi Sumatera Utara laju inflasi secara nasional sebesar 11,05 \% di tahun 1997 dan $77,63 \%$ tahun 1998. Gejolak tersebut yang membuat perekonomian Indonesia yang ditinjau secara makro dan mikro tidak menguntungkan dan sangat berpengaruh terhadap tingkat produktifitas, sehingga menghantarkan Indonesia masuk kedalam kelompok negara-negara berkembang, seperti pernyataan yang dikemukakan oleh Todaro (2000) bahwa: "Ciri-ciri dari negara berkembang adalah standar hidup yang rendah, dengan produktivitas yang rendah (low level of productivity).

Di sisi lain pemerintah menunjukkan ketidakberdayaannya untuk mengatasinya, dikarenakan keterbatasan modal dan keterbatasan tabungan masyarakat yang dapat disumbangkan untuk pembangunan. Ini berdampak semakin berkurangnya produktivitas masyarakat, sehingga pertumbuhan ekonomi juga menurun. Padahal produktivitas dipengaruhi oleh berbagai faktor, baik yang berasal dari tenaga kerja maupun yang berhubungan dengan lingkungan perusahaan serta kebijakan pemerintah secara keseluruhan, seperti: pendidikan, kesehatan, gizi, keterampilan, disiplin kerja, kesempatan kerja, tingkat upah dan jaminan sosial. Konsekuensi dari rendahnya pendidikan menyebabkan produktivitas pekerja rendah. Jika produktivitas rendah, maka berakibat pendapatannya rendah, tabungan rendah dan modal rendah. Sementara modal merupakan salah satu faktor yang mempengaruhi pertumbuhan ekonomi.

Krisis ekonomi mengakibatkan banyaknya industri yang mengalami kebangkrutan atau mengurangi produksinya, sehingga banyak pekerja yang pindah dari perkotaan ke pedesaan, yang diikuti pula oleh meningkatnya persentase tenaga kerja yang bergerak di sektor pertanian. Krisis ekonomi juga menumbuhkan keyakinan kembali bahwa sektor pertanian dapat berperan sebagai motor penggerak pertumbuhan ekonomi atau sebagai penyelamat perekonomian, serta konstribusi sektor pertanian menunjukkan angka yang positif dari tahun 1999 ke tahun 2000, hal ini dapat dilihat pada Tabel 1.

Tabel 1: Pendapatan Regional Kota Medan

\begin{tabular}{|c|c|c|}
\hline \multirow{2}{*}{ Tahun } & \multicolumn{2}{|c|}{ Lapangan Usaha } \\
\cline { 2 - 3 } & Pertanian & Industri \\
\hline 1994 & 10,78 & 5,13 \\
\hline 1995 & 9,73 & 4,88 \\
\hline 1996 & 6,51 & 11,57 \\
\hline 1997 & 6,92 & 6,37 \\
\hline 1998 & 1,18 & $-22,16$ \\
\hline 1999 & 1,28 & 1,35 \\
\hline 2000 & 9,43 & 3,25 \\
\hline 2001 & 4,68 & 4,96 \\
\hline 2002 & 6,88 & 0,50 \\
\hline
\end{tabular}

Sumber : BPS $1993-2002$ 
Dari Tabel $1 \mathrm{di}$ atas dapat dilihat bahwa terjadi penurunan pertumbuhan ekonomi di sektor industri yang sangat drastis dari 6,37 tahun 1997 menjadi -22,16 tahun 1998, dan terjadi peningkatan pertumbuhan ekonomi di sektor pertanian yaitu sebesar 1,28 di tahun 1999 dan 9,43 di tahun 2000.

Bila dianalisa secara mendalam pada tahun 1998 terjadi masa puncak krisis, sehingga pertumbuhan ekonomi berada pada $-22,16 \%$. Saat ini terjadi pengangguran cukup besar, tetapi masyarakat masih menunggu adanya harapan untuk kembali mendapatkan pekerjaan. Bagi masyarakat desa yang tidak memiliki tanah merupakan golongan miskin yang paling miskin. Di dareah perkotaan mayoritas kaum miskin adalah tidak terlatih di sektor-sektor industri, tetapi umumnya mereka lebih kaya dari kaum miskin di pedesaan. Masyarakat miskin di pedesaan identik dengan kemiskinan alamiah yakni kemiskinan yang disebabkan kurangnya sumber daya masyarakat terhadap tanah pertanian dalam meningkatkan pembangunan ekonomi mereka, sedang masyarakat miskin perkotaan identik dengan kemiskinan struktural, yaitu kemiskinan yang disebabkan oleh perubahanperubahan ekonomi dan teknologi dalam pembangunan itu sendiri. (Muliani, 2004)

Ciri-ciri masyarakat miskin Indonesia adalah kebanyakan mereka tinggal di pedesaan dengan tingkat pendidikan yang rendah, bahkan tidak tamat SD, tidak memiliki faktor produksi sendiri, seperti tanah yang cukup, modal atau kurangnya keterampilan, sehingga kemampuan untuk memperoleh pendapatan terbatas. Sedangkan yang hidup di kota berusia muda dan tidak mempunyai keterampilan, sehingga tidak jarang mereka ini tetap menjadi miskin dan akhirnya terdampar dalam kantong-kantong kemelaratan (Slump area) di tengah-tengah masyarakat maju akibat dorongan modal, keterampilan dan kemajuan teknologi (Salim, 1980).

Kurangnya tanah pertanian merupakan sebab utama bagi penduduk desa menjadi miskin. Hal ini disebabkan berbagai macam faktor, misalnya adanya pengalihan hak atas tanah pertanian rakyat kepada orang-orang kaya di kota. Bagi penduduk miskin yang tinggal di desa dekat dengan pusat kota banyak bermobilisasi sebagai migrasi kommuter (mobilitas ulang alik). Meskipun mereka menyadari di kota tidak mudah untuk mendapatkan pekerjaan, mereka memiliki harapan bahwa kota dapat memberikan apa yang diharapkan, baik pekerjaan maupun fasilitas. Dengan melaksanakan migrasi kommuter merek berharap akan memperoleh pendapatan yang lebih besar untuk mengatasi beban ekonomi, yang pada akhirnya dapat meningkatkan taraf hidup keluarga mereka secara layak. Pendapatan yang mereka peroleh bervariasi sesuai dengan tingkatan pendidikan dan jenis pekerjaan yang mereka kerjakan.

Berdasarkan uraian latar belakang di atas, maka peneliti merumuskan masalah yang akan diteliti yaitu: Faktor-faktor Apa yang mempengaruhi migrasi Sirkuler di kota Medan? dan Apakah terdapat Pengaruh Jenis pekerjaan, tingkat pendidikan, fasilitas kota, daya dorong desa, kepemilikan tanah terhadap migrasi sirkuler di kota Medan. 


\section{DESKRIPSI TEORITIS}

\section{Sejarah Migasi sirkuler}

Dalam sejarah, migrasi besar-besaran timbul secara serentak sejalan dengan lahirnya revolusi industri di Eropah pada abad 18 dan 19 juli dan telah mengundang tenaga kerja dari desa untuk bekerja di kota dan pusat-pusat industri. Dalam beberapa studi, pengertian mengenai migrasi dan mobilitas penduduk sering disamaartikan. Pada dasarnya mobilitas penduduk adalah pergerakan penduduk secara geografis. Perbedaan kedua istilah hanya terletak pada permanen dan non permanen.

Hasil penelitian yang dilakukan oleh Gantjang (Muliani, 2004) memperlihatkan bahwa pada saat krisis ekonomi 44,7\% dari 1662 RT yang dijadikan sampel adalah migran kembali (return migrant), 15,4\% merupakan migran yang baru tiba dan $4,6 \%$ adalah migran sirkuler. Selanjutnya ia juga menyatakan sedikitnya migrasi sirkuler yang ditemukan pada studi ini yang menunjukkan indikasi bahwa krisis membuat mereka tidak dapat tinggal di suatu tempat, karena mereka harus mencari kesempatan ekonomi kemanapun mereka pergi. Menurut Mulyani (2004) migrasi adalah perpindahan penduduk dari satu tempat di tempat lain untuk menetap. Migrasi penduduk antar daerah telah lama terjadi, ada yang spontan ada yang disponsori oleh pemerintah. Selanjutnya Mulyadi (2002) mendefinisikan penduduk migran dalam dua kategori, yaitu pertama, mereka yang pada saat pencacahan tempat tinggalnya berbeda dengan tempat lahir yang disebut migrasi semasa hidup (life time migration). Kedua, mereka yang tempat tinggal lima tahun lalu, dikategorikan sebagai migrasi risen (recent migration). Masalah migrasi membawa permasalahan tersendiri bagi daerah perkotaan, karena migrasi merupakan gerak alamiah yang mengikuti perkembangan ekonomi. Selama disparitas antara desa dan kota semakin melebar, maka arus imigrasi sulit untuk dibendung.

Selanjutnya Furqon (1998) mengatakan bahwa kegiatan perekonomian kita masih sangat terpusat di Jabotabek. Di kawasan ini peredaran uangnya mencapai $73 \%$ dari total peredaran uang nasional. Itu sebabnya pola urbanisasi yang muncul selama ini lebih terkonsentrasi di wilayah ini. Selain permasalahan di atas dampak urbanisasi dapat menyebabkan meningkatnya kebutuhan lapangan pekerjaan di kota dan dapat mempengaruhi pasar tenaga kerja. Hal ini mengakibatkan kurangnya tenaga kerja yang potensial tersedia di desa. Di Yogyakarta misalnya sempat mengalami pertumbuhan penduduk sampai minus 0,12. Di dareah-daerah tersebut lebih banyak penduduk yang berusia tua dan perempuan. (Kompas, 19 Februari 1997). Migrasi penduduk bisa menghambat pembangunan di desa, misalnya kebutuhan tenaga untuk kerja musiman pada saat panen, sehingga menjadi permasalahan di desa. Migrasi penduduk juga dapat menciptakan pemukiman-pemukiman kumuh dan gejolak sosial di kota.

Di negara Berkembang, konsentrasi investasi dan sumber daya pada umumnya berada di dareah perkotaan. Karena konsentrasi investasi di beberapa pusat pertumbuhan biasanya terjadi sebagai akibat dari keuntungan lokasi dalam 
skala ekonomi, sehingga ketimpangan antar daerah semakin terakumulasi. Menurut Rondinelli dan Ruddle (Tjiptoherijanto, 1997) keuntungan komparatif dari pusat pertumbuhan menjadi seperti magnet bagi kegiatan industri, jasa, sosial dan kebudayaan. Daerah pedesaan tidak memberi insentif bagi warganya, kekurangan tanah akan mendorong masyarakat desa untuk meninggalkan desa dan berpindah ke kota. Ada 2 faktor yang menjadi penyebab terjadinya urbanisasi adalah karena faktor daya tarik (pull factors) kota dan daya dorong (push factor) dari desa.

Menurut Lee, keputusan seseorang untuk bermobilisasi selain ditentukan oleh faktor-faktor individu juga ditentukan oleh kondisi suatu daerah asal dan tujuan (Muliani, 2004). Seseorang akan tetap tinggal Di dareah asal, melakukan ulang alik atau berimigrasi ditentukan oleh bertemu atau tidaknya antara kebutuhan individu dan kondisi suatu daerah (Matra, 1991). Maksudnya seseorang memutuskan berimigrasi yang didominasi oleh motif ekonomi, karena didorong kondisi daerah tersebut mampu atau tidaknya daerah tersebut dapat memenuhi kebutuhan hidup. Dengan melakukan mobilisasi di daerah lain, seseorang akan berharap dapat menemukan kesempatan ekonomi yang lebih baik. Meskipun tidak selamanya penduduk desa yang berimigrasi langsung mendapatkan pekerjaan yang diinginkannya. Secara umum seorang migran sirkuler ingin bermobilisasi ke kota dipengaruhi oleh faktor utama ekonomi, di samping faktor sosial dan kejiwaan.

Dari tinjauan di atas, dapat ditarik beberapa faktor pokok penyebab terjadinya migrasi adalah:

1. Proses kemiskinan di desa.

2. Lapangan kerja yang hampir tidak ada.

3. Pendapatan yang rendah.

4. Keamanan.

5. Adat istiadat yang ketat.

6. Melanjutkan pendidikan.

Dari pernyataan di atas tiga hal pertama adalah yang sangat mendasar dalam membuat keputusan untuk berimigrasi dari desa ke kota. Kita ketahui bahwa desa yang perekonomiannya masih subsistem dan sangat didominasi oleh sektor pertanian dan hasilnya sangat dipengaruhi jumlah tenaga kerja, iklim, luas tanah, sehingga hasilnya pun sangat terbatas dan mengakibatkan pendapatan rendah.

Selain itu mobilitas seorang dari desa ke kota juga ditentukan oleh faktor jarak, biaya dan informasi antar tempat asal dengan kota daerah tujuan berjarak jauh juga mendorong seseorang akan melakukan mobilitas permanen (migrasi), bila berjarak sedang akan menghasilkan mobilitas menginap/mondok, bila berjarak dekat cukup dilakukan secara ulang alik/commuting (Matra, 1991).

\section{Model Pembangunan Lewis}

Menurut model pembangunan yang diajukan Lewis (Todaro, 2000) yang dikenal dengan Model dua sektor lewis (lewis two sector model). Bahwa perekonomian di negara berkembang terdiri dari dua sektor yakni: 
1. Sektor tradisional, yakni sektor pedesaan subsisten yang surplus tenaga kerja, ditandai denga Marginal Tenagan Kerja sama dengan nol (0)

2. Sektor Industri perkotaan modern yang tingkat produktivitasnya tinggi serta menjadi tempat penempungan tenaga kerja dari sektor subsisten .

Titik perhatian model ini adalah proses perpindahan tenaga kerja dan pertumbuhan tingkat pengerjaan (employment) di sektor modern, dengan asumsi bahwa tingkat upah daerah perkotaan sekurang-kurangnya harus $30 \%$ lebih tinggi dari pada rata-rata pendapatan di dareah pedesaan, sehingga memaksa pekerja untuk berpindah dari pedesaan ke daerah perkotaan. Sedangkan perpindahan tenaga kerja dan pertumbuhan pengerjaan di perkotaan menyebabkan pertumbuhan output di sektor modern.

Penelitian yang pernah dilakukan oleh Hugo (Mulyadi, 2002) pada tahun 1989 di Jawa Barat menemukan bahwa perpindahan penduduk, baik yang bersifat permanen maupun tidak permanen merupakan suatu respon terhadap tekanan dari lingkungan, baik dalam bentuk ekonomi, sosial maupun demografi yang berpengaruh secara khusus terhadap tekanan-tekanan tersebut.

Hasil studi yang dilakukan Naim (Mulyadi, 2002) atas suku Minang mengungkapkan adanya kecenderungan suku Minang untuk bermigrasi telah berakar dan melembaga dalam sistem sosial suku bangsa tersebut, dan ditemukan bahwa keputusan bermigrasi ditentukan oleh faktor-faktor yang menekan di dareah asal dan faktor sosial budaya. Setelah keputusan itu dibuat baru ditentukan kemana arah berimigrasi yang akan dituju. Penelitian Suharso (Mulyadi, 2002) memperkuat pendapat adanya kaitan antara migrasi dengan aspek ekonomi; dikatakannya bahwa sebagian orang bermigrasi dikarenakan tidak memiliki tanah dan pekerjaan tetap. Jadi tujuan utamanya untuk mendapatkan pekerjaan.

\section{Kerangka Konseptual dan Hipotesis Penelitian.}

Dari landasan teori di atas dapat dibuat kerangka konseptual sebagai berikut:

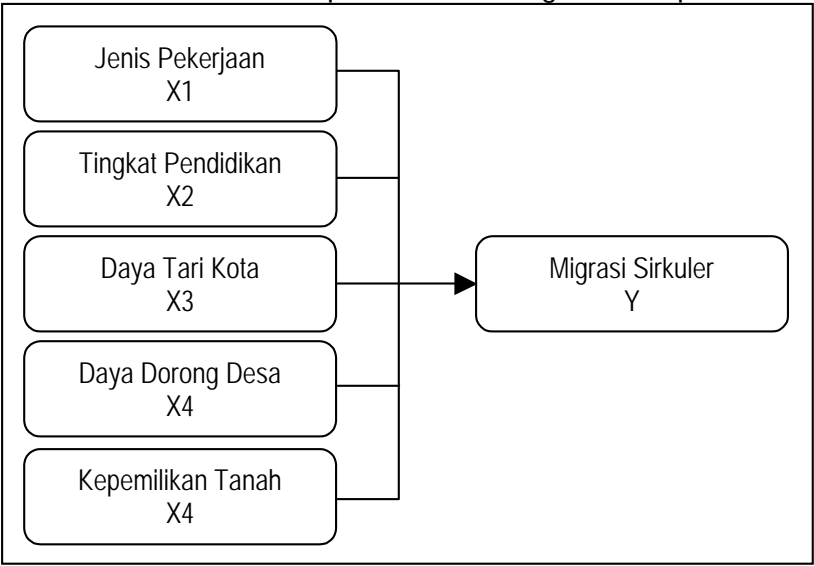

Gambar 1: Kerangka Konseptual Peneitian 
Sedangkan hipotesis penelitian ditentukan sebagai berikut: terdapat Pengaruh Jenis pekerjaan, tingkat pendidikan, fasilitas kota, daya dorong desa, kepemilikan tanah terhadap migrasi sirkuler di kota Medan.

\section{METODE PENELITIAN}

Populasi dalam penelitian ini adalah masyarakat yang melakukan migrasi dan yang bekerja pada sektor formal di Medan, dengan penariakan sampel secara convenience sampling. Kuesioner sebanyak 200 eksemplar mulai didistribusikan sejak September 2006 sampai Desember 2006. Jumlah kuesioner yang kembali sebanyak 135, tetapi yang lengkap dan dapat diolah hanya 128 , sehingga tingkat pengembalian responden (responden rate) sebesar $64 \%$.

Variabel yang digunakan sebagi bahan analisis dalam penelitian ini dimaksud adalah sebagai berikut:

Migrasi atau Tidak Migrasi (Y). Dumy Variabel 0 dan 1 digunakan untuk mendefinisikan responden dimana angka 1 untuk migrasi dan 0 untuk tidak migrasi. Dalam penelitian migran sirkuler adalah variabel dependen yang dibuat dalam dua kategori yakni yang bermigrasi dan yang tidak bermigrasi sirkuler. Migran Sirkuler adalah penduduk yang bergerak melewati batas administrasi daerah tertentu dari desa ke kota yang melakukan kegiatan ekonomi, pergi pagi pulang petang dengan tidak berniat untuk menetap di kota tujuan. Sedang yang tidak bermigrasi sirkuler, boleh penduduk yang pindah dari desa ke kota untuk menetap di kota, atau penduduk kota yang telah lama tinggal di kota. Penduduk yang dimaksud adalah penduduk laki-laki dan perempuan. Dalam penelitian ini variabel dibuat variabel dummy, untuk migran sirkuler diberi nilai satu dan yang tidak berkommuter diberi nilai nol.

Jenis Pekerjaan (X1). Jenis perkerjaan yang dimaksud adalah jenis pekerja formal responden yang di proksi sebagai: karyawan swasta, dan PNS/TNI/POLRI. Jenis pekerjaan yang dimaksud adalah jenis pekerjaan yang ditekuni pada saat mereka tinggal di desa atau belum bekerja di kota, dan variabel jenis pekerjaan dibuat variabel dummy yang dikelompokkan dalam dua kelompok, yakni wiraswasta diberi nilai satu dan PNS diberi nilai nol.

Tingkat Pendidikan (X2). Yang dimaksud tingkat pendidikan adalah jenjang pendidikan terakhir responden yang diperoleh melalui pendidikan formal, baik di sekolah negeri maupun swasta, atau sekolah yang sederajat yang diakui pemerintah, baik mendapat ijazah maupun yang tidak mendapat ijazah. Tingkat pendidikan dalam penelitian adalah variabel dummy yang dibagi dalam dua kelompok yaitu:

1. Tingkat dasar dan atas: SMU sederajat dan dibawah SD dan SLTP dan sederajatnya diberi nilai 0 .

2. Tingkat Perguruan tinggi: Sarjana, sarjana muda dan ahli madia diberi nilai 1. 
Daya tarik kota (pull factors). Faktor daya tarik kota di proksi ke dalam variabel fasilitas di kota dan daya dorong dari desa.

Fasilitas di kota (X3) Medan. Diukur dengan ketersediaan kesehatan, pendidikan, seni dan budaya, agama, kemudahan dalam trasportasi dan fasilitas umum, dan birokrasi di kota yang lebih mudah.

Daya dorong (push factor) dari desa (X4). Dinilai berdasarkan tingkat keamanan di desa, lapangan kerja dan upah serta adat istiadat

Status Kepemilikan Tanah (X5). Status kepemilikan tanah dalam penelitian ini dibuat variabel dummy yakni yang memiliki tanah diberi nilai satu, yang tidak memilki tanah diberi nilai nol.

Penelitian ini juga menguji asumsi klasik yang melekat pada persamaan model regresi sehingga data-data yang digunakan dalam pengujian hipotesis bebas dari asumsi klasik (Ghozali, 2001).

Untuk pengujian Hipotesis, penelitian ini menggunakan analisis Regresi berganda (Multiple regression), karena terdapat lebih dari satu variabel independen (Hair, 1998). Model persamaan regresi untuk pengujian Hipotesis dapat diuraikan sebagai berikut :

$L i=\operatorname{Ln}\left(\frac{P i}{P i-1}\right)=\beta 0+\beta 1 \times 1+\beta 2 \times 2+\beta 3 \times 3+\beta 4 \times 4+\beta 5 \times 5+e$.

Keterangan :

$\mathrm{a}=$ Constanta

$\beta=$ Koefisien Regresi

$Y=$ Pentingnya Penerapan Akuntansi Sosial Perusahaan (Corporate Social Accounting Importance)

$\mathrm{x} 1=$ Jenis Pekerjaan

$\mathrm{x} 2$ = Tingkat Pendidikan

$\mathrm{x} 3$ = Fasilitas Kota

$\mathrm{x} 4$ = Daya Dorong Desa

x5 = Status Kepemilikan Tanah

\section{PEMBAHASAN DAN HASIL}

Penelitian ini melibatkan responden dengan gambaran sebagai berikut:

Sebagian besar responden penelitian ini adalah berjenis kelamin Pria (65\%) dan sisanya sebanyak (35\%) adalah wanita. Umur responden diklasifikasikan dalam 5 kategori terdiri dari responden yang berumur di bawah 15 s/d 25 tahun sekitar $46 \%$. Kemudian responden berumur antara 26 s/d 35 tahun sebanyak 23\%, yang berumur antara $36 \mathrm{~s} / \mathrm{d} 45$ tahun atau sekitar $18 \%$, serta $7 \%$ berumur $46 \mathrm{~s} / \mathrm{d} 55$ tahun dan di atas 55 tahun atau sekitar 7\%.

Distribusi responden berdasarkan pekerjaannya menunjukkan responden yang berkerja sebagai karyawan swasta sekitar 44\%, kemudian responden yang 
berkerja sebagai PNS/TNI/POLRI sebanyak 26\%, yang berkerja sebagai wiraswasta atau sekitar 19\%, serta 5\% pensiunan dan lainnya 6\%. Pendidikan Responden diklasifikasikan dalam 5 kategori, terdiri dari $45 \%$ berpendidikan S1, berpendidikan D1 41\%, dan siasanya berpendidikan SMU/SMK 14\%.

Dari hasil pengujian menggunakan regresi logit di dapat hasil sebagai berikut:

Omnibus Test of Model Coefficients
\begin{tabular}{|ll|c|c|c|}
\hline \multicolumn{1}{|c|}{} & Chi-square & Df & Sig. \\
\hline Step 1 & Step & 16,682 & 5 &, 005 \\
& Block & 16,682 & 5 &, 005 \\
& Model & 16,682 & 5 &, 005 \\
\hline
\end{tabular}

\begin{tabular}{|l|c|c|c|}
\hline Model Summary \\
\hline Step & -2 Log & $\begin{array}{c}\text { Cox \& Snell R } \\
\text { Square }\end{array}$ & $\begin{array}{c}\text { Nagelkerke } \\
\text { R Square }\end{array}$ \\
\hline 1 & 159,181 &, 123 &, 164 \\
\hline
\end{tabular}

Dari pengujian tersebut di peroleh chi-squere 16,682 dengan signifikansi 0,005 , sehingga disimpulkan bahwa secara simultan terdapat pengaruh variabel jenis pekerjaan, tingkat pendidikan, fasilitas kota, daya dorong desa, kepemilikan tanah terhadap migrasi sirkuler di kota Medan. Hasil ini konsisten dengan Penelitian yang dilakukan Zulkifli (2004) dan Muliani (2004). Adapun besarnya pengaruh terhadap migrasi sirkuler di kota Medan sebesar 12,3\%.

Variables in the Equation

\begin{tabular}{|ll|r|r|r|r|r|r|}
\hline & & \multicolumn{1}{|c|}{ B } & \multicolumn{1}{c|}{ S.E. } & \multicolumn{1}{c|}{ Wald } & \multicolumn{1}{c|}{ df } & \multicolumn{1}{c|}{ Sig. } & \multicolumn{1}{c|}{$\operatorname{Exp(B)}$} \\
\hline Step & VAR00011 &,- 221 &, 569 &, 151 & 1 &, 698 &, 802 \\
1 & VAR00012 & 1,573 &, 503 & 9,778 & 1 &, 002 & 4,822 \\
& VAR00013 &,- 030 &, 047 &, 404 & 1 &, 525 &, 971 \\
& VAR00014 &,- 006 &, 142 &, 002 & 1 &, 966 &, 994 \\
& VAR00015 &,- 537 &, 449 & 1,432 & 1 &, 231 &, 584 \\
& Constant &, 564 & 2,038 &, 077 & 1 &, 782 & 1,757 \\
\hline
\end{tabular}

a. Variable(s) entered on step 1: VAR00011, VAR00012, VAR00013, VAR00014, VAR00

Secara parsial diketahui hanya variabel tingkat pendidikan yang berpengaruh terhadap migrasi sirkuler di kota Medan $(p=0.002<5 \%)$. Sedangkan jenis pekerjaan $(p=0.698)$, fasilitas kota $(p=0.525)$, daya dorong desa $(p=0.231)$ dan status kepemilikan tanah $(p=0.792)$ tidak berpengaruh terhadap migrasi sirkuler di kota Medan.

Penelitian ini memiliki keterbatasan antara lain:

1. Penarikan sampel dengan convenience sampling. Cara ini ditempuh karena tidak terdapatnya data yang pasti mengenai besarnya jumlah dan identifikasi 
masyarakat yang melakukan migrasi sirkuler di Medan. Hal ini dikhawatirkan mempengaruhi hasil penelitian.

2. Sampel penelitian ini hanya pada pekerja sektor formal penelitian. Pada penelitian selanjutnya dapat dikembangkan pada perkerja sektor informal dengan jumlah sampel yang lebih besar.

\section{DAFTAR PUSTAKA}

Bobo Julius (2003), Transformasi Ekonomi Rakyat, PT Pustaka Cidesindo Jakarta.

Dumary (1996), Perekonomian Indonesia, Penerbit Erlangga, Jakarta.

Furqon, Ukon Ahmad (1998), Urbanisasi dan Hubungan Desa-Kota di Indonesia, ITB Bandung.

Hair, Anderson and Tathan Black (1998), Multivariat Data Analysis, Fifth Edition, Prentice Hall.

Ghozali, Imam (2001), Aplikasi Analisis Multivariat dengan Program SPSS, Badan Penerbit Universitas Diponegoro.

Harsa, Putra (2002), Kamus Lengkap Bahasa Indonesia, Penerbit Putra Harsa, Surabaya.

Muliani, Izah (2004), Analisis Faktor-faktor Yang Mempengaruhi Migrasi Sirkuler Di Kota Medan (Studi Kasus Pada Pekerja Sektor Informal, Tesis Pasca Sarjana (Tidak Dipublikasikan), Universitas Islam Medan.

Kompas, 19 Februari 1997, Dampak Migrasi terhadap Pertanian di Jogjakarta.

Matra, Ida Bagus (1991), Mobilitas Migrasi Sirkuler dari Desa ke Kota Indonesia, Seri Kertas Kerja No: 30, Pusat Penelitian Kependudukan UGM.

BPS Kota Medan (2002), Medan dalam angka.

Salim, Emil (1980), Perancangan Pembangunan Dan Pemerataan Pembangunan, Yayasan Indayu, Jakarta.

Mulyadi, Subri (2002), Ekonomi Sumber Daya Manusia, PT Raja Grafindo Persada, Jakarta.

Tjiptoherijanto, Prijono (1997), Migrasi Urbanisasi dan Pasar Kerja di Indonesia, Penerbit Universitas Indonesia Jakarta.

Todaro, Michael P (2000), Pembangunan Ekonomi Didunia Ketiga, Penerbit Erlangga, Jakarta.

Zulkifli (2004), Migrasi Sirkuler dalam Perkembangan Wilayah Kabupaten Langkat, Tesis Pasca Sarjana (Tidak Dipublikasikan), Universitas Sumatra Utara. 